and D. George (eds.)

\title{
The market features of imported non-indigenous polychaetes in Portugal and consequent ecological concerns
}

\author{
PEDRO FIDALGO E COSTA ${ }^{1,2}$, JOÃO GIL $^{3}$, ANA MARIA PASSOS ${ }^{2}$, PAULA PEREIRA ${ }^{4}$, \\ PEDRO MELO ${ }^{5}$, FREDERICO BATISTA $^{4}$ and LUIS CANCELA DA FONSECA ${ }^{2,6}$ \\ ${ }^{1}$ Escola Superior de Educação João de Deus, Av. Álvares Cabral, 69, 1269-094, Lisboa, Portugal. \\ ${ }^{2}$ IMAR/Laboratório Marítimo da Guia, Estrada do Guincho, P-2750-374 Cascais, Portugal. E-mail: pedro.f.c@ @etcabo.pt \\ ${ }^{3}$ Centre d'Estudis Avançats de Blanes (CSIC), Carrer d'accés a la Cala Sant Francesc, 14, E-17300 Blanes, Girona, Spain. \\ ${ }^{4}$ INIAP/IPIMAR - CRIPSul, Av. 5 de Outubro, P-8700-305 Olhão, Portugal. \\ ${ }^{5}$ Direcção-Geral de Veterinária (PIF Lisboa), Av. Brasília, Ed. Alfândega, Alcântara Norte, 1300 Lisboa, Portugal. \\ ${ }^{6}$ FCMA, Universidade do Algarve, Campus de Gambelas, P-8005-139 Faro, Portugal.
}

SUMMARY: The importance of the market for polychaetes dramatically increased after the discovery of their potential as food in aquaculture. In Portugal, the gathering of polychaetes solely from natural populations is not sufficient to meet market demand, both as bait for sea anglers and as a food item in aquaculture. The requests for worms to polychaete dealers by Portuguese and Spanish seafarms have increased during recent years. Due to the lack of intensive culture of these worms in Portugal and the proximity of southern Spanish farms, a large component of imported polychaetes that arrive in Portugal at Lisbon Airport go directly to Spain by road. In 2002 and 2003 a total of 12,728,379 and 16,866,839 polychaetes respectively were imported to Europe via Lisbon Airport from China and the USA. In 2003 the imports from China and the USA realised 716,180 and 291,845 US dollars respectively. Two species were reported to have been imported in these years, namely the Korean blue ragworm Perinereis aibuhitensis and the American bloodworm Glycera dibranchiata. Imports of non-indigenous species, which are traded and sold alive, may increase the risk of accidental introduction into the wild. This is of special concern as Perinereis aibuhitensis has been successfully reared in captivity within the range of environmental conditions existing in the Ria Formosa coastal lagoon. Other risks associated with introduced species are the transport of foreign pathogens and other associated non-native organisms, which may act as carriers of disease.

Keywords: Polychaeta, Perinereis aibuhitensis, Glycera dibranchiata, bait, non-indigenous species, Portugal.

RESUMEN: LAS CARACTERÍSTICAS DEL MERCADO DE POLIQUETOS NO AUTÓCTONOS EN PORTUGAL Y SUS IMPLICACIONES ECOLÓGICAS. - La importancia de la comercialización de los poliquetos aumentó de forma notable con el descubrimiento de su potencial como alimento en la acuicultura. En Portugal, la recogida de poliquetos únicamente de las poblaciones naturales no es suficiente para suplir la demanda del mercado, que se centra tanto en cebo para la pesca con caña como en alimento para la acuicultura. En los últimos años, los pedidos de gusanos a los proveedores de poliquetos por parte de las piscifactorías portuguesas y españolas han aumentado. Debido a la ausencia de cultivos intensivos de estos gusanos en Portugal y a la proximidad de las piscifactorías del sur de España, una gran parte de los poliquetos importados que llegan a Portugal a través del Aeropuerto de Lisboa van directamente a España por carretera. En los años 2002 y 2003, un total de 12,728,379 y 16,866,839 poliquetos de China y EE.UU., respectivamente, fueron exportados a Europa vía el Aeropuerto de Lisboa. En el año 2003 estos dos origines representaron por este mismo orden, 716.180 y 291.845 dólares americanos. Las dos especies importadas durantes estos años fueron el gusano coreano Perinereis aibuhitensis y el americano Glycera dibranchiata. La importación de especies no autóctonas que son comercializadas y vendidas vivas, puede incrementar el riesgo de ser introducidas accidentalmente en el ambiente. Esto es especialmente preocupante ya que la especie Perinereis aibuhitensis ha sido criada con éxito en cautividad en condiciones ambientales próximas a las encontradas en la laguna costera de Ria Formosa. Otros riesgos asociados con las especies introducidas son el transporte de patógenos extraños y otros organismos asociados no nativos, que pueden actuar como portadores de enfermedades.

Palabras clave: Polychaeta, Perinereis aibuhitensis, Glycera dibranchiate, cebo de pesca, especies alóctonas, Portugal. 


\section{INTRODUCTION}

The ancient activity of worm-collecting on sediment shores where dense worm aggregations are present is frequently observed in different countries. Several families of polychaetes are exploited notably: Arenicolidae, Glyceridae, Nereididae, Nephtyidae and Eunicidae (Olive, 1994). Their commercial importance as a resource has been increased since the use of polychaetes as a food source is now well established in the aquaculture of penaeid Crustacea and finfish mainly of the family Soleiidae, (Dinis, 1986; Olive, 1994). The demand for worms for use as sea angling baits has lead to the development of a small but economically viable aquaculture sector providing different cultured species (Gambi et al., 1994; Olive et al., 2000). The production, however, is still insufficient to supply the market demand (Olive, 1994).

In Portugal, as in the United Kingdom, several types of exploitation can be recognised with a illdefined boundary between anglers collecting strictly for their 'own use' and those collecting bait to sell to others (Olive, 1993). This undefined exploitation contributes to a parallel economy and directly conflicts with a sustainable and controlled activity. Portuguese legislation to regulate bait digging originates in 2000 (Portaria $\mathrm{n}^{\circ} 1102-\mathrm{B} / 2000$ ) and applies exclusively to the exploitation of Marphysa sanguinea (Montagu, 1815), Diopatra neapolitana Delle Chiaje, 1841 and Nereis diversicolor O.F. Müller, 1776. Although legislation exists, control of the catch and policies to exploit baitworm stock in a sustainable way such as progressive exploitation of areas alternating with periods of recovery, is not in evidence.

With regards to the introduction of non-indigenous species, the current legislation and guidelines put forward in 1999 are very restrictive (DL $\mathrm{n}^{\circ} 565 / 1999$ ). Although international obligations, such as those from the Bern, Bonn and Biodiversity Conventions, are followed, this document does not make any reference to the introduction of live bait into Portugal, even though imports are becoming widespread, particularly within European Mediterranean countries (Fowler, 1999).

In Portugal the gathering of polychaetes solely from natural populations is not sufficient to meet market demand, both as bait for sea anglers and as a food item in aquaculture. The request for worms from polychaete dealers by Portuguese and Spanish fish and crustacean seafarms have increased during recent years. Due to the lack of intensive culture of these worms in Portugal, a large component of the worm market consists of imported polychaetes. Most of them arrive at Lisbon Airport and go straight to Spain by road. Some are labelled as "coreano" (korean worm) and are commonly sold at retail outlets along the coast.

Worms from China, Vietnam and the USA were registered at Lisbon Airport during 2002 and 2003. According to our surveys only the organisms arriving from China and the USA were polychaetes. Every one of the "live sea worms" from Vietnam were sipunculans. The main aim of this study is to present the data from 2002 to 2003 on non-native polychaete species that arrive weekly at Lisbon Airport. The use of polychaetes as live bait, the potential risks of them becoming established in the wild, and the dangers of the introduction of foreign parasites and/or vectors of diseases are also discussed.

\section{MATERIAL AND METHODS}

All live marine worms imported into Portugal arrived at Lisbon Airport every Monday and Friday in refrigerated containers maintained at around $5^{\circ} \mathrm{C}$ to reduce worm metabolism, assuring survival. The countries of origin were the USA, China and Vietnam, and veterinary requirements were based on documentation from export and import authorities. Visual inspection was undertaken to check the conservation condition and worm survival in each packing case. No bacteriological analysis was carried out to find any potential risks of bacterial and/or virus introduction, even though some worms originated in tropical/subtropical wetlands.

The customs registers relating to imported live sea worms in 2002 and 2003 were analysed taking note of origin and destination, species numbers (annual and monthly totals), and market value. Afterwards, and independent of the customs process, identification of the species was made on random samples from the biological material obtained at Lisbon Airport. This was performed to identify the species in the cases where its specific identity was omitted and/or to confirm the scientific name presented in the animal health certificate accompanying the package. These samples were also counted to validate the numbers existing in the 
registers. The relationship between weight and number of individuals was also investigated.

\section{China}

Before leaving China the worms were subjected to veterinary inspection by the Shanghai authorities, certifying that live worms originate from non-infected areas and that they met the veterinary requirements of China.

They were packed in two different boxes, depending on the importer: i) cardboard boxes $(50 \times 30 \mathrm{~cm})$ divided into two chambers, each chamber with four layers of Styrofoam ${ }^{\circledR}$ chessboards $(20 \times 20 \mathrm{~cm})$, containing fermented paper pulp as bedding material and filled up with polychaetes or ii) cardboard boxes containing eight layers of forty small Styrofoam ${ }^{\circledR}$ boxes with ten worms in each box.

\section{USA}

The animals come with a Veterinary Certificate, stating that worms came from an area controlled by the Official Veterinary Service. The declaration presented by this agency states that no disease listed on the A list of the O.I.E. (World Organization for Animal Health) or any other disease which could affect humans or could be transmitted through other animals has been detected in collecting areas or in a $5 \mathrm{~km}$ radius at least three months prior to shipping. Each container must have its own certificate.

Worms were packaged in cardboard boxes $(50 \times 30 \mathrm{~cm})$, with four layers of Styrofoam ${ }^{\circledR}$ chessboards $(20 \times 40 \mathrm{~cm})$, containing fermented paper pulp as the bedding material and filled up with polychaetes.

\section{Vietnam}

Also categorised as "live sea worms", the sipunculans exported from Vietnam to Portugal arrives in cardboard boxes $(50 \times 30 \mathrm{~cm})$, piled up with 60 plastic boxes each containing ten worms, with moist plastic foam as bedding material.

\section{RESULTS}

The Animal Health Certificate of "live lugworms" from China referred to these species as Perinereis vancaurica or Perinereis tetradentica.
From our surveys we found only the nereidid Perinereis aibuhitensis (Grube, 1878) in the polychaetes imported from that country. The USA Veterinary Certificate refers to the sea worms from that origin as the American Blood Worm Glycera dibranchiata Ehlers, 1868 (Glyceridae), harvested in the USA (Maine). Our surveys confirmed this identification. The specimens imported from Vietnam and categorised as "live sea worms", were found to be sipunculans (Sipunculus nudus L., SaizSalinas pers. comm.) and not polychaetes. Our monitoring confirmed the numbers that had been declared in the registers.

Globally, data available from 2002 and 2003 show that from a total of $34,867,367$ marine sea worms that arrived at Lisbon Airport, 29,595,218 were polychaetes (ca. 85\%), the remainder $5,272,149$ (ca. 15\%), all from Vietnam, being sipunculans. Data from each year show an increase in polychaetes arriving from China (P. aibuhitensis), a slight decrease in those coming from the USA $(G$. dibranchiata) and a great increase of sipunculans (Fig. 1).

Concerning total weight combined for both years, polychaetes represented $88,213 \mathrm{~kg}$ (ca. $89.1 \%$ ) and sipunculans $10,820 \mathrm{~kg}$ (ca. 10.9\%). Nevertheless, while the relative values of the total annual weight of polychaetes showed little variation between 2002 and 2003 (respectively, 43,634 and $44,579 \mathrm{~kg}$ ), the weight of the sipunculans increased about ten times in the same period (from 999 to $9821 \mathrm{~kg}$ ).

Almost all imported polychaetes from the USA were destined for Spain with numbers remaining approximately the same during 2002 and 2003. The numbers of polychaetes imported from China into Portugal destined for the Spanish market also remained approximately the same during 2002 and 2003. Those destined for the Portuguese market showed an increase during the same period (Fig. 2).

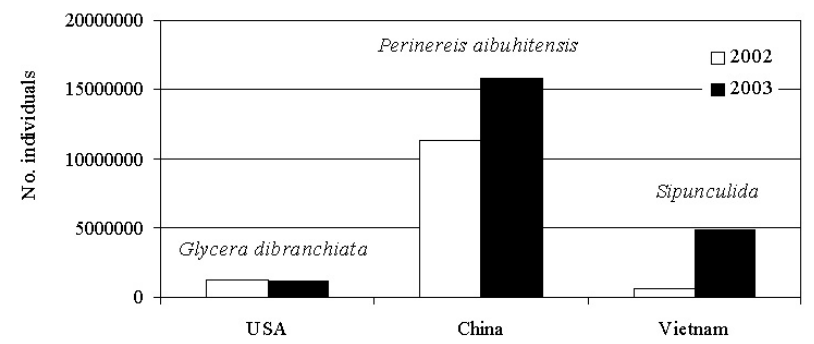

FIG. 1. - Origin of live sea worms arriving at Lisbon Airport during 2002 and 2003. 
No. Individuals - 2002

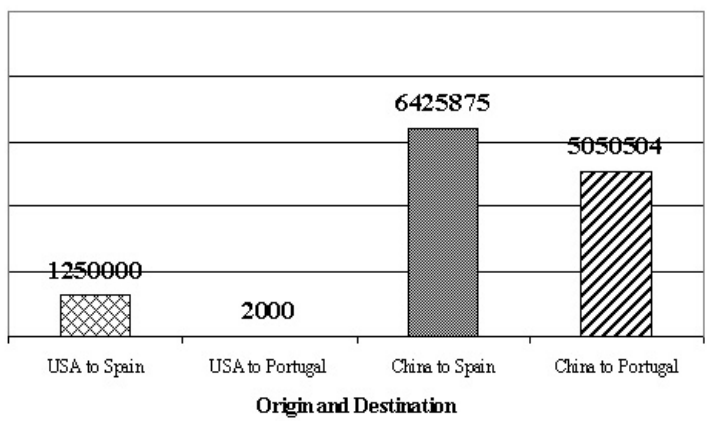

No. Individuals - 2003

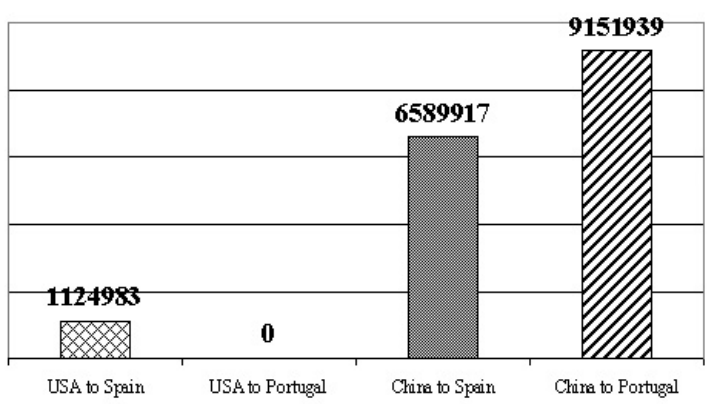

Origin and Destimation
Total Weight $(\mathrm{kg})$ - 2002

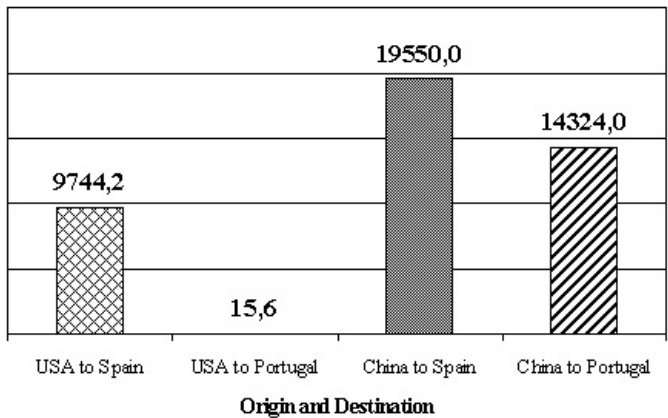

Total Weight (kg) - 2003

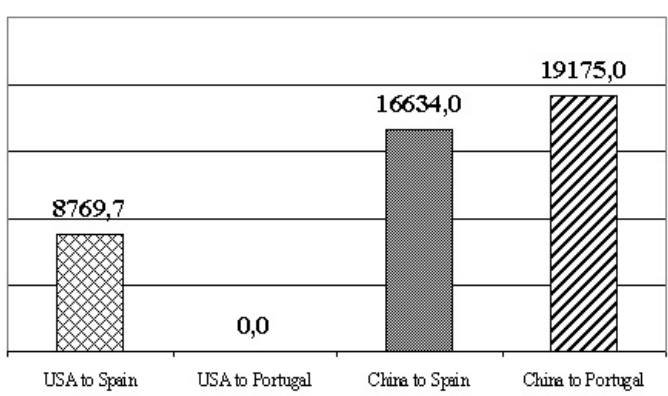

Origin and Destination

FIG. 2. - Number of individuals, total weight and destination of polychaetes arriving at Lisbon Airport during 2002 and 2003.

Some differences in numbers have been detected between months. The majority of imported polychaetes arrived during the spring and summer months (see Fig. 3).

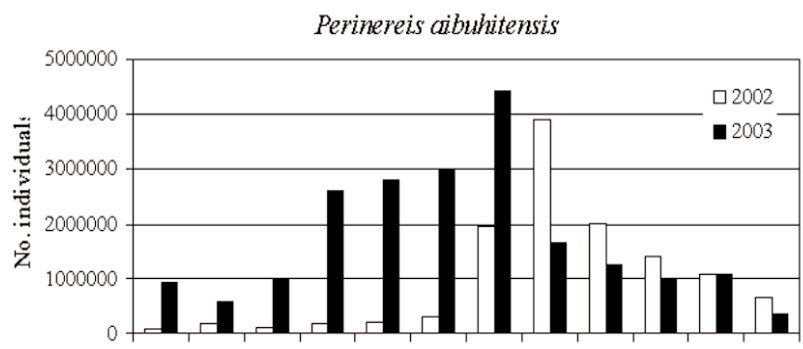

Jan Feb Mar Apr May Jun Jul Aug Sept Oct Nov Dec

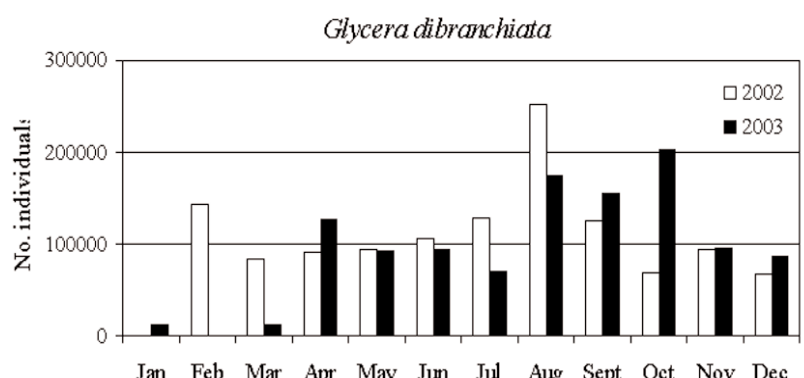

FIG. 3. - Monthly polychaete arrivals at Lisbon Airport (2002 and 2003).
The available data on market value refers only to the year 2003 and to polychaetes (Lisbon Airport, unpublished data). According to these data, polychaetes imported during this year through Lisbon Airport from China and the USA represented 716,180 and 291,845 US dollars respectively.

\section{DISCUSSION}

Like other emerging businesses worm-gathering has increased since it was found that polychaetes could provide a nutritionally correct balance of polyunsaturated fatty acids, which are essential for maturation in different aquacultured species (Dinis, 1986; Lytle et al., 1990). This contributes to explain the differences in the arrival times of imported polychaetes throughout the year. The increase during the spring and summer might be a consequence of a higher demand from the aquaculture industry in these periods related to the maturation and reproduction of reared species in Portugal and Spain (Pousão-Ferreira, pers. comm.). Another important reason for that increase is their use as fresh bait in sport and professional fishing which also increases during those months. 
Several species support well established commercial fisheries that have been sustained over several decades. Such fisheries can only develop with a substantial population and the fishery frequently has an important role for the country's regional economies (Olive, 1994). The main routes of distributions of wild-caught polychaetes cited by Olive (1994) are from the South China Sea (Korea and mainland China) into Japan but with increasing quantities being transported from Korea to Europe and the USA; and also from the NE Coast of the USA (Maine) to Europe. Ten years later, all imported polychaetes arriving in Lisbon come only from China and the USA (also sipunculans from Vietnam) and not from Korea. This may be due to a strong development of the Chinese and Vietnamese economies.

The worldwide trade of live bait could be assumed to be an expanding industry and the risk associated with the introduction of non-indigenous species must be considered, especially because the numbers of imported baits from wild stocks to European countries are not yet well-known (Fowler, 1999). Non-indigenous aquatic species could be defined as a member(s) (individual, group, or population) of a species that enters a body of water or aquatic ecosystem outside its historic or native range through two processes: range expansions and introductions. Most of the introductions are the result of human activities (Carlton, 1987; Wade, 1995).

A number of non-indigenous imported polychaetes may have life cycles and growth rates that make them more suitable candidates for farming than other native bait worms. The commercial returns from introducing such species to the bait market can be very large, but the probability of introductions into the wild would be high, either through discharge of farm tank effluents or the use of live worms for bait (Fowler, 1999). As an example, Perinereis aibuhitensis has been successfully reared in captivity by the INIAP/IPIMAR Tavira Pilot Aquaculture Station (unpublished data), both from wild imported specimens and from individuals born and grown in experimental circumstances, within the range of environmental conditions prevalent in the Ria Formosa coastal lagoon (a Natural Park in south Portugal). According to the preliminary results this species also seems to be able to reproduce in coastal lagoons and estuaries of south Portugal. The impact of its eventual introduction could include competitive displacement or predation of native species. Nereis diversicolor $(=$ Hediste diversicolor), for instance, lives in the upper littoral zone, in the same range of salinity, with the same spawning period, and identical production/biomass ratio and secondary production as Perinereis aibuhitensis (Choi and Lee, 1997; Fidalgo e Costa et al., 1998; Fidalgo e Costa, 2003).

The most significant method of accidently introducing non-indigenous species to different regions of the world, has been via commercial shipping. Ballast-water discharge and colonisation of ships' hulls by fouling organisms, has been recognized as a major factor creating a long-distance dispersal method for marine organisms, foreign parasites, and human pathogens. Shipping may also be responsible for the worldwide distribution of microorganisms, as well as for carrying waterborne diseases affecting plants and animals (Ruiz et al., 2000). Similar risks may result from the international trade of live bait. One species of polychaete (Namalycastis sp.) imported from Vietnam and sold as "Nuclear Worms" in retail shops in the Chesapeake Bay region (USA) showed that vibrio bacteria might be present in its packing material (Sherfy and Thompson, 2001).

The commercial harvesting of polychaetes has strong implications at the community and environmental level (McLusky et al., 1983; Kaiser et al., 2001; Falcão et al., in press). The disturbance of feeding shore birds coupled with the reduction in available prey items because of competition with the bait diggers, as well as the effect on the habitat itself is of great concern (Evans and Clarke, 1993). To reduce and overcome these environmental problems, and also those associated with the impact of introduction of non-indigenous species, commercial rearing of native species is an attractive solution (Gambi et al., 1994; Olive, 1994). The environmental benefits that may be gained from increasing bait farming and reducing bait-digging activity are considerable. Many anglers would prefer to purchase cultured bait rather than dig their own if supplies are of high quality, and priced advantageously in relation to some of the worms collected from the wild (Olive and Cowin, 1994; Fowler, 1999). Aquaculturalists are now carrying out commercial scale trials, feeding different species with farmed ragworms with special profiles of nutritional lipids and fatty acids (Olive, 1994). Developments in the culture of bait species using locally caught brood stocks also provide an important potential for the 
artificial restocking of depleted bait worm populations (Fowler, 1999).

\section{ACKNOWLEDGEMENTS}

The authors would like to thank Dr. Michael Heasman for improving the English on the manuscript, Dr. Susana Pinedo for translating the abstract into Spanish, and Dr. José Saiz-Salinas for identifying the Vietnamese sipunculans. We are also grateful to three anonymous referees for their valuable criticisms and suggestions and to the management team of Lisbon Airport and staff of its Veterinary Service for their collaboration.

\section{REFERENCES}

Carlton, J.T. - 1987. Patterns of transoceanic marina biological invasions in the Pacific Ocean. Bull. Mar. Sci., 41(2): 452-465.

Choi, J.-W. and J.-H. Lee. - 1997. Secondary production of a nereid species, Perinereis aibuhitensis in the intertidal mudflat of the west coast of Korea. Bull. Mar. Sci., 60: 517-588.

Dinis, M.T. - 1986. Quatre Soleidae de l'estuaire du Tage: reproduction et croissance essai d'elevage de Solea senegalensis Kaup. PhD. thesis, Univ. Bretagne Occidentale, Brest.

Decreto-lei nº56/99-1999. Espécies não indígenas da Flora e da Fauna. Diário da República, 21/12/1999, série I-A, no 295: 9100-9114.

Evans, J. and N.A. Clark. - 1993. Disturbance studies on Swansea Bay on the Burry Inlet in relation to bird populations. BTO Research Report No 107, 84 pp.

Falcão, M., M. Caetano, D. Serpa, M. Gaspar and C. Vale. - (in press). Effects of infauna harvesting on tidal flats of a coastal lagoon (Ria Formosa - Portugal): implications on phosphorus dynamics. Mar. Environ. Res.

Fidalgo e Costa, P. - 2003. The oogenic cycle of Nereis diversicolor (Annelida: Polychaeta) in shallow waters environments in southwestern Portugal. Bol. Inst. Esp. Oceanogr. 19(1-4): 17-29.

Fidalgo e Costa, P., L. Cancela da Fonseca and R. Sardá. - 1998. Life cycle, growth and production of the polychaete Nereis (Hediste) diversicolor O.F. Müller in three estuary lagoon systems of the southwestern portuguese coast (Odeceixe, Aljezur and Carrapateira). Écologie, 29(4): 523-533.

Fowler, S.L. - 1999. Guidelines for managing the collection of bait and other shoreline animals within UK European marine sites. English Nature (UK Marine SACs Project), 132 p.

Gambi, M.C., A. Castelli, A. Giangrande, P. Lanera, D. Prevedelli and R. Zunarelli Vandini. - 1994. Polychaetes of commercial and applied interest in Italy: an overview. In: J.-C. Dauvin, L. Laubier and D.J. Reish (eds.), Actes de la 4ème Conférence Internationale des Polychètes. Mem. Mus. Nat. Hist.Nat. (Fr.), 162: 593-603.

Kaiser, M.J., G. Broad and S.J. Hall. - 2001. Disturbance of intertidal soft-sediment benthic communities by cockle hand raking. J. Sea Res., 45: 119-130.

Lytle, J.S., T.F. Lytle and J.T. Ogle. - 1990. Polyunsaturated fatty acid profiles as a comparative tool in assessing maturation diets of Penaeus vannamei. Aquaculture, 89: 287-299.

McLusky, D.S., F.E. Anderson and S. Wolfe-Murphy. - 1983. Distribution and population recovery of Arenicola marina and other benthic fauna after bait digging. Mar. Ecol. Progr. Ser., 11: 173-179.

Olive, P.J.W. - 1993. Management of the exploitation of the lugworm Arenicola marina and the ragworm Nereis virens (Polychaeta) in conservation areas: the importance of population structure and recruitment processes. Aquat. Conserv., 3: 1-24.

Olive, P.J.W. - 1994. Polychaeta as a world resource: a review of patterns of exploitation as sea angling bait and the potential for aquaculture based production. In: J.-C. Dauvin, L. Laubier and D.J. Reish (eds.), Actes de la 4ème Conférence Internationale des Polychètes. Mem. Mus. Nat. Hist. Nat. (Fr.), 162: 603-610.

Olive, P.J.W., M. Islam and P.B.D. Cowin. - 2000. Cultured Polychaeta: a dietary resource to increase penaeid hatchery performance. European Aquaculture Society, Spec. publ., 28: 523.

Olive, P.J.W. and P.B.D. Cowin. - 1994. The management of natural stocks and the commercial culture of Polychaeta as solutions to the problems of "bait-digging" and worm supply for sea angling in the UK. Polychaete Res., 16: 23-27.

Portaria $\mathrm{n}^{\circ} 1102-\mathrm{B} / 2000$. - 2000. Regulamento da Apanha. Diário da República, 21/11/2000, série I-B, no 270: 6692-(4)-6692-(9).

Ruiz, G.M., P.F. Fofonoff, J.T. Carlton, M.J. Wonham, A.H. Hines and A. Cohen. - 2000. Invasion of coastal marine communities in North America: patterns and processes. Ann. Rev. Ecol. Syst., 31: 481-531.

Sherfy M.H. and J.A. Thompson. - 2001. Potential risk of aquatic invasive species introduction due to international trade in live bait. In: J. Reaser (ed.), Preventing the introduction and spread of aquatic invasive species in North America. Workshop Proceedings, pp. 22-24. Commission for Environmental Cooperation, Montreal Quebec, Canada.

Wade, S.A. - 1995. Stemming the tide: a plea for new exotic species legislation. J. Land Use Environ. Law, 10: 343-370.

Received September 15, 2004. Accepeted May 11, 2005. 